\title{
Development and validation of RP-HPLC assay of chlorhexidine in gingival crevicular fluid
}

\section{Liljana Bogdanovska ${ }^{1}$, Sehmedin Saliu ${ }^{2}$, Mirjana Popovska ${ }^{2}$, Aneta Dimitrovska ${ }^{1}$, Liljana Ugrinova ${ }^{1}$, Rumenka Petkovska ${ }^{1}$}

${ }^{1}$ Department of Applied Chemistry and Pharmaceutical Analysis, Faculty of Pharmacy, University "Ss. Cyril and Methodius", Mother Teresa 47, Skopje,

Republic of Macedonia

${ }^{2}$ Department of Oral Pathology and Periodontology, Faculty of Dentistry, University "Ss. Cyril and Methodius", Mother Teresa 47, Skopje,

Republic of Macedonia

"Corresponding author, e-mail: lbogdanovska@ff.ukim.edu.mk

\section{Summary}

A reversed - phase HPLC method with UV detection for determination of chlorhexidine in gingival crevicular fluid (GCF) was optimized and validated, using chlorpheniramine as an internal standard. The chromatographic separation was performed on Discovery C18 HPLC column with $0.01 \mathrm{~mol} \mathrm{~L}^{-1}$ phosphate buffer $(\mathrm{pH}=3.0)$, triethylamine and acetonitrile $(66: 1: 33$, $V / V / V)$, as mobile phase. Under the optimized HPLC conditions, linearity was obtained in the range of 0.5-5.0 $\mu \mathrm{g} \mathrm{mL}^{-1}$ with LOD $0.07 \mu \mathrm{g} \mathrm{mL}^{-1}$ and LLOQ $0.5 \mu \mathrm{g} \mathrm{mL}^{-1}$. The described method can be successfully applied for determination of chlorhexidine concentrations in GCF obtained from patients with chronic periodontal disease treated with PerioChip ${ }^{\mathrm{TM}}$.

Key words: chlorhexidine digluconate, PerioChip ${ }^{\mathrm{TM}}$, RP-HPLC, gingival crevicular fluid, periodontal disease 


\section{Introduction}

It is widely accepted that the inflammatory periodontal disease is caused by bacteria in the dental plaque. However, its nature depends to a large extent on the interaction between periopathogenic bacteria, the environment and the response of the host's defense mechanisms to the bacterial assault [1]. Gingival crevicular fluid (GCF) is a serum transudate or inflammatory exudate and can be collected from periodontal pockets in patients suffering from periodontal disease [2]. GCF consists of cellular elements, electrolytes, organic compounds, metabolic and bacterial products and enzyme and enzyme inhibitors. Although very similar to serum, GCF contains much less proteins [3].

The most commonly used therapy for periodontal disease consists of supra - and subgingival plaque and calculus removal (scaling and root planning, SRP). Although SRP is essential in management of healthy periodontium, it can be time-consuming, unpleasant for patients and technically difficult to perform [4]. In adjunction to SRP, antibiotics and antiseptics have been used successfully to treat moderate to severe forms of periodontal disease [4]. Systemically and locally applied antibiotics as well as locally applied antiseptics are administered to improve periodontal health of patients treated with SRP [5].

Although systemic administration of antibiotics is an effective approach to alter the progression of certain forms of periodontitis, there are several disadvantages such as inadequate therapeutic concentrations at the site of action, gastrointestinal disturbances, hypersensitivity and development of bacterial resistance. Its drawbacks can be overcomed by local application of antimicrobial or antiseptic agents using controlleddelivery systems applied into periodontal pockets [6].

Chlorhexidine (CHX), 1.1'-hexamethylene-bis [5-(4-chlorophenyl) biguanide] (Figure 1A), is an antimicrobial and cationic bisbiguanide that possesses a broad spectrum of antibacterial activity and shows substantivity, safety and lack of toxicity [7]. Applied locally, $\mathrm{CHX}$ has been shown to inhibit a large number of bacterial species found in the subgingival plaque at concentrations of $125 \mu \mathrm{g} \mathrm{mL}^{-1}$ [8]. 


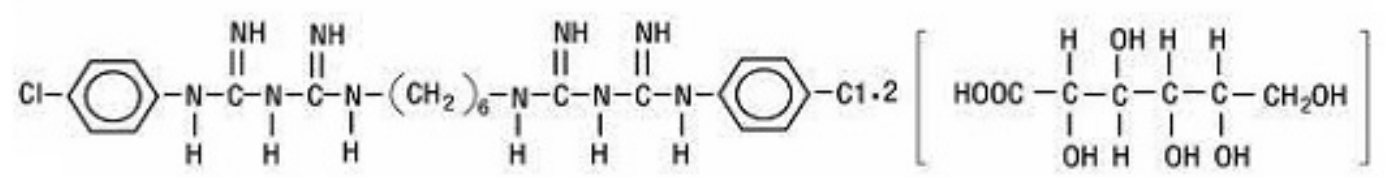

A

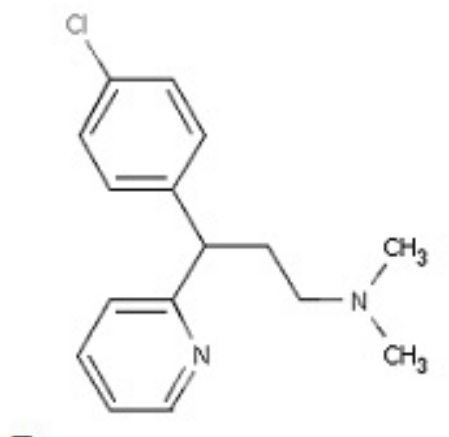

B

Figure 1. A) Structure of chlorhexidine digluconate B) Chlorpheniramine maleate

Slika 1. A) Struktura hlorheksidin glukonata B) Hlorfeniramin maleata

Usually, CHX does not achieve effective concentrations within the periodontal pockets for sufficiently long period of time, thus subgingival irrigation with CHX solutions is usually not effective in the treatment of periodontitis [8]. The PerioChip ${ }^{\mathrm{TM}}$ is a biodegradable local drug delivery system that releases chlorhexidine in periodontal pockets over 7-10 days. Several clinical trials have shown that the PerioChip ${ }^{\mathrm{TM}}$ used as adjunct to SRP significantly aids in reducing probing pocket depths $[9,10]$.

Previous studies have reported quantification of chlorhexidine in saliva [11], whole blood [12] and serum [13] by HPLC with UV or MS detection. LC-MS methods are sensitive and selective, but require highly qualified personnel and expensive instrumentation. To the best of our knowledge, only one HPLC method with UV detection for determination of $\mathrm{CHX}$ in GCF has been developed, which employed ionpair reagent in the mobile phase [9].

The main purpose of this study was to develop a simple, sensitive and reliable RP HPLC method for quantification of CHX in GCF. Therefore, this study was focused on the development, optimization and validation of a simple bioanalytical RP-HPLC 
method that can be employed for routine analysis of CHX concentrations in GCF after the PerioChip ${ }^{\mathrm{TM}}$ application in periodontal pockets.

\section{Materials and methods}

\section{Chemicals and materials}

Chlorhexidine digluconate and chlorpheniramine maleate (internal standard, IS) were provided by Sigma Aldrich (Germany) and Supriya Lifescience Ltd. (India). Methanol and acetonitrile (HPLC grade) were supplied by Carlo Erba, Italy. Analytical grade sodium phosphate $\left(\mathrm{Na}_{3} \mathrm{PO}_{4}\right)$, triethylamine (TEA) and phosphoric acid were purchased from Sigma Aldrich (Germany). HPLC grade water was used for chromatographic analysis. Whatman 3MM chromatography paper strips $2 \mathrm{~mm}$ x $5 \mathrm{~mm}$ (Whatman Lab Sales Ltd., UK) were used for GCF collection. Human serum was obtained from healthy volunteers (Department of Periodontology, Faculty of Dentistry, University of "Ss. Cyril and Methodius", Skopje, Macedonia). PerioChip ${ }^{\mathrm{TM}}$ containing $2.5 \mathrm{mg}$ of chlorhexidine digluconate was supplied by Perio Products Ltd., Jerusalem, Israel.

\section{Collection of GCF samples}

GCF samples were obtained from 30 patients suffering from chronic periodontitis. The patients had at least 2 periodontal pockets with probing pocket depths of $\geq 5 \mathrm{~mm}$. A single chip was placed into each predetermined periodontal pocket using dental forceps, after isolation and drying the associated tooth. The PerioChip ${ }^{\mathrm{TM}}$ completely decomposes after 7-10 days of placement. GCF samples were collected after 1 and after 24 hours of PerioChip $^{\mathrm{TM}}$ placement and then after 2, 4, 6 and 7 days. GCF was collected applying the method of Koss et al. In brief, the paper strips were placed in the selected periodontal pockets until mild resistance was felt and left in place for $30 \mathrm{~s} \mathrm{[14].}$

\section{Apparatus and chromatographic conditions}

The HPLC analysis was conducted on Shimadzu Nexera HPLC system equipped with UV diode array detector. The chromatographic separation was performed on Discovery C18, $250 \mathrm{~mm} \times 4.6 \mathrm{~mm}, 5 \mu \mathrm{m}$ (Supelco, USA) at $25^{\circ} \mathrm{C}$. The mobile phase was acetonitrile, $0.01 \mathrm{~mol} \mathrm{~L}^{-1}$ phosphate buffer adjusted to $\mathrm{pH}=3.0$ with phosphoric acid and triethylamine $(33: 66: 1, V / V / V)$. Flow rate was $1 \mathrm{~mL} \mathrm{~min}^{-1}$. The injection volume was $50 \mu \mathrm{L}$ and the $\mathrm{UV}$ detection was performed at $253 \mathrm{~nm}$. The total run time for the HPLC analysis was $10 \mathrm{~min}$. 


\section{Preparation of standard solutions and quality control (QC) samples}

Stock standard solutions of chlorhexidine digluconate $\left(1.0 \mathrm{mg} \mathrm{mL} \mathrm{m}^{-1}\right)$ and chlorpheniramine maleate $\left(1.0 \mathrm{mg} \mathrm{mL}^{-1}\right)$ were prepared in methanol and refrigerated at $4{ }^{\circ} \mathrm{C}$ in dark volumetric flasks. Working standard solutions of CHX were made daily by diluting the stock standard solution of $\mathrm{CHX}$ with mobile phase to concentrations of $50.0,75.0,100.0,125.0,150.0,200.0$ and $500.0 \mu \mathrm{g} \mathrm{mL}^{-1}$. Working standard solution of IS was made daily by diluting the stock standard solution of IS with mobile phase to concentration of $125.0 \mu \mathrm{g} \mathrm{mL} \mathrm{mL}^{-1}$. Calibration curve standard solutions were prepared using working standard solutions of CHX and IS on 7 paper strips previously spiked with $2 \mu \mathrm{L}$ of serum, using the following procedure: $2 \mu \mathrm{L}$ of separate $\mathrm{CHX}$ working standard solution and $15 \mu \mathrm{L}$ of IS working standard solution were added to each paper strip. Paper strips were extracted with $200 \mu \mathrm{L}$ of acetonitrile. Final concentrations of calibration curve standard solutions were $0.50,0.75,1.0,1.25,1.50,2.0$ and $5.0 \mu \mathrm{g} \mathrm{ml}^{-1}$. QC (Quality Control) sample solutions were prepared in the same manner as calibration curve standard solutions in concentrations of $0.50,1.50,2.50$ and $4.00 \mu \mathrm{g} \mathrm{ml}^{-1}$ and stored at $-20{ }^{\circ} \mathrm{C}$. GCF exists as a serum transudate, therefore calibration curve standard solutions and QC samples were prepared in serum because GCF is not commercially available nor easily collectable in large volumes [15].

\section{GCF sample preparation}

After collection of GCF, paper strips were removed and placed in preweighted Eppendorf tubes and kept at $-20{ }^{\circ} \mathrm{C}$ until analysis. Before the HPLC analysis, GCF samples were thawed at room temperature. $15 \mu \mathrm{L}$ from $100 \mu \mathrm{g} \mathrm{mL}^{-1}$ IS solution was added to the GCF sample. After adding acetonitrile as an extracting solvent up to volume of $200 \mu \mathrm{L}$, the GCF sample solutions were vortex mixed for 3 minutes. The liquid content of the tubes was transferred to glass autosampler vials. Injection volume was $50 \mu \mathrm{L}$. The weight of the fluid was calculated as a difference between the mass of the strips before GCF collection and after their application in the pocket. The obtained value, expressed as $\mu \mathrm{g}$, was converted to volume in $\mu \mathrm{L}$ assuming the density of GCF was $1 \mathrm{mg} \mathrm{mL} \mathrm{m}^{-1}$ [14]. The concentration of CHX in GCF samples obtained from patients was calculated by multiplying the value obtained after the HPLC analysis by factor $200 / \mathrm{V}$, where $\mathrm{V}$ is the volume of the GCF samples expressed in $\mu \mathrm{L}$.

\section{Validation procedure for the bioanalytical HPLC method}

The validation of the developed bioanalytical RP HPLC method for determination of CHX in GCF was performed according to EMA (European Medicines Agency) Guideline for validation of bioanalytical methods [16]. 
Linearity-The calibration line was constructed with seven calibration standards in the range from 0.50 to $5.00 \mu \mathrm{g} \mathrm{mL} \mathrm{m}^{-1} \mathrm{CHX}$, including LLOQ (Lower Limit of Quantification) and the ULOQ (Upper Limit of Quantification). The calibration curve was obtained using linear regression analysis of CHX peak area to internal standard peak area ratio vs. concentration. Limit of detection (LOD) was calculated as the concentration level resulting in peak area three times the baseline noise. Selectivity Selectivity of the method was investigated by comparing blank GCF sample solutions and QC sample solutions containing $0.50 \mu \mathrm{g} \mathrm{mL}^{-1} \mathrm{CHX}$.

Accuracy and precision - Intra-day accuracy and precision was determined using five replicates of each of the following QC sample solutions: 0.50, 1.50, 2.50 and 4.00 $\mu \mathrm{g} \mathrm{mL}{ }^{-1}$ which represent $L L O Q$, low QC sample (LQC), medium QC sample (MQC) and high QC sample (HQC), respectively. The QC sample solutions were analyzed on the same day to establish intra-day accuracy and precision and on three different days to investigate inter-day accuracy and precision.

Recovery - The extraction recovery for CHX and IS were calculated by comparing the peak areas measured after extraction of five replicates of QC sample solutions in the following concentrations: $0.50,1.50,2.50$ and $4.00 \mu \mathrm{g} \mathrm{mL}{ }^{-1}$ with peak areas of solutions with the same concentration prepared in mobile phase.

Stability - CHX sample solution stability was tested by chromatographic analysis of QC samples at LQC and HQC levels. The freeze-thaw stability $\left(36 \mathrm{~h}\right.$ at $-20^{\circ} \mathrm{C}$, three cycles), short-term stability ( $2 \mathrm{~h}$, room temperature), long-term stability (30 days, - $20{ }^{\circ} \mathrm{C}$ ) and autosampler stability (immediately after extraction and 16 hours after preparation) were investigated.

\section{Results and discussion}

\section{HPLC method's optimization}

Chromatographic conditions were varied to achieve efficient separation of CHX and the IS from the components of the matrix and a chromatographic response in a short run time per analysis for both the analyte and IS. During preliminary investigations, mobile phase composition, flow rate and injection volume were optimized. Several mobile phases containing $0.01 \mathrm{~mol} \mathrm{~L}^{-1}$ phosphate buffer $(\mathrm{pH}=3.0)$ and acetonitrile were investigated where the composition of the organic phase varied from $20 \%-40 \%$. It was observed that a mobile phase consisting of acetonitrile, $0.01 \mathrm{~mol} \mathrm{~L}^{-1}$ phosphate buffer $(\mathrm{pH}=3.0)$ and triethylamine $(33: 66: 1, V / V / V)$ was the most appropriate choice. In order to reduce the peak tailing, $1 \%$ triethylamine was used. The flow rate was investigated in the range from $0.5-1.5 \mathrm{~mL} \mathrm{~min}^{-1}$ and the final flow rate was set to be $1.0 \mathrm{~mL} \mathrm{~min}^{-1}$. The injected sample volume was tested in the range from $20 \mu \mathrm{L}$ to $50 \mu \mathrm{L}$ in order to achieve the required sensitivity, accuracy and precision for selective 
determination of CHX in GCF. It was found that $50 \mu \mathrm{L}$ was optimal volume to obtain maximal peak enhancement, especially for the extracted samples in which the lowest concentration of $\mathrm{CHX}$ was expected.

Chlorpheniramine shows similar chromatographic behavior, elutes near CHX and does not interfere with components from the sample matrix. Therefore, it was selected as internal standard for this method. The structure of the IS is shown in Figure 1B. $\mathrm{ACN}$ was chosen as the extracting solvent because of the high extraction power for both CHX and the IS.

\section{HPLC method's validation}

System suitability

The system suitability test was an integral part of the chromatographic method development and it was used to verify that the system was adequate for the analysis to be performed. The suitability of the chromatographic system was demonstrated by the retention time, resolution, plate number, tailing factor and retention factor values are shown in Table I.

Table I System suitability parameters

Tabela I Parametri za proveru pogodnosti sistema

\begin{tabular}{ccc}
\hline \hline Parameter & CHX & IS \\
\hline \hline Retention time $\left(\mathrm{t}_{\mathrm{R}}\right)(\mathrm{min})$ & 7.14 & 5.01 \\
Resolution $\left(\mathrm{R}_{\mathrm{s}}\right)$ & 7.094 & 4.518 \\
Number of theoretical plates & 5852 & 7462 \\
$(\mathrm{~N})(\mathrm{USP})$ & 1.339 & 1.244 \\
Tailing factor $\left(\mathrm{T}_{\mathrm{f}}\right)$ & 1.8 & 1.01 \\
Retention factor $(\mathrm{k})$ & & \\
\hline \hline
\end{tabular}

\section{Linearity}

Good linearity was observed in the range from $0.50 \mu \mathrm{g} \mathrm{mL}^{-1}-5.00 \mu \mathrm{g} \mathrm{mL} L^{-1}$. Coefficient of determination $\mathrm{R}^{2}$ was 0.9911 , the LOD was $0.07 \mu \mathrm{g} \mathrm{mL}^{-1}$ and the LLOQ was $0.50 \mu \mathrm{g} \mathrm{mL}^{-1}$. 
Linear regression equation for CHX in GCF was $y=(0.5926 \pm 0.02) x-$ $(0.0014 \pm 0.05)$. All analytical parameters of the linear regression equations were calculated for confidence interval of $95 \%$.

\section{Selectivity}

The chromatograms of blank GCF and GCF spiked with CHX and IS are presented in Fig. 2. As shown in Fig. 2b, no endogenous interferences were found the retention times of $\mathrm{CHX}$ and GCF, confirming the selectivity of the method. Well separated peaks of IS and CHX were obtained at approximately $5.01 \mathrm{~min}$. and 7.14 min., respectively.

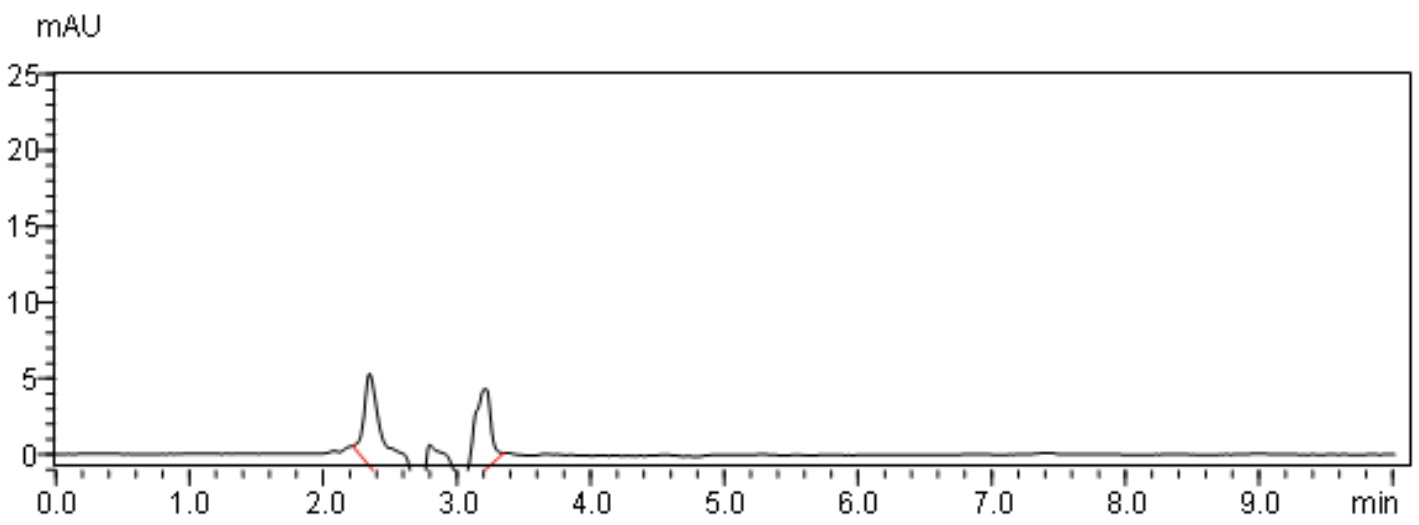

Figure 2A. Representative chromatogram of a blank GCF sample

Slika 2A. Reprezentativni hromatogram blanka GCF uzorka

MAU

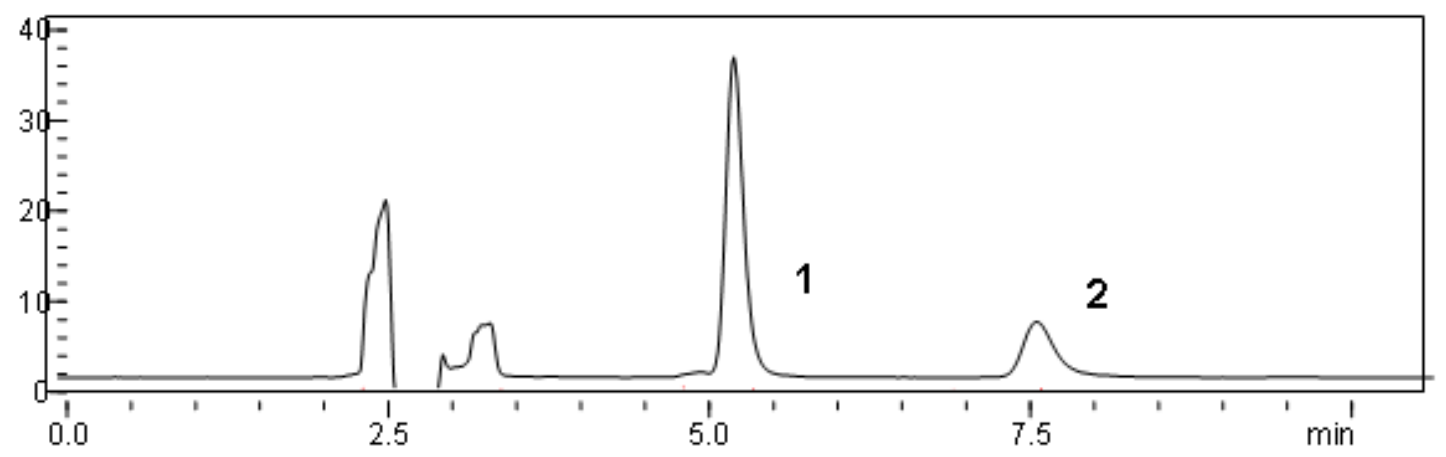

Figure 2B. Representative chromatogram of a blank GCF sample spiked with $0.50 \mu \mathrm{g} \mathrm{mL}^{-1} \mathrm{CHX}(2)$ and $10.00 \mu \mathrm{g} \mathrm{mL}^{-1}$ IS (1)

Slika 2B. Reprezentativni hromatogram blanka GCF uzorka opeterćen sa $0,50 \mu \mathrm{g} \mathrm{mL} \mathrm{L}^{-1}$ CHX (2) i $10,00 \mu \mathrm{g} \mathrm{mL}^{-1}$ IS (1) 


\section{Accuracy and precision}

The intra-day and inter-day accuracy and precision are shown in Table I. The mean of intra- and inter- day accuracy were in the range $98.3 \%-101.9 \%$ and $100.3 \%-106.02 \%$, respectively. RSD values for intra- and inter- day precision were $3.98 \%-5.66 \%$ and $0.56 \%-4.30 \%$.

Table II Precision and accuracy of the proposed method

Tabela II Preciznost i tačnost metode

\begin{tabular}{ccccc}
\hline \hline & $\begin{array}{c}\text { CHX in QC } \\
\text { sample } \\
\left(\mu \mathrm{g} \mathrm{mL}^{-1}\right)\end{array}$ & $\begin{array}{c}\text { Found CHX } \\
\left(\mu \mathrm{g} \mathrm{mL}^{-1}\right)^{\mathrm{a}}\end{array}$ & $\begin{array}{c}\text { Accuracy } \\
(\%)\end{array}$ & $\begin{array}{c}\text { Precision } \\
(\mathrm{CV}, \%)\end{array}$ \\
\hline \hline \multirow{3}{*}{ Intra-day $(n=5)$} & 0.50 & $0.49 \pm 0.03$ & 98.39 & 5.66 \\
& 1.50 & $1.50 \pm 0.08$ & 99.76 & 5.12 \\
& 2.50 & $2.44 \pm 0.10$ & 99.68 & 3.98 \\
& 4.00 & $4.08 \pm 0.17$ & 101.91 & 4.23 \\
\hline \multirow{3}{*}{ Inter-day $(n=30)$} & 0.50 & $0.50 \pm 0.02$ & 100.30 & 4.30 \\
& 1.50 & $1.54 \pm 0.05$ & 102.41 & 3.13 \\
& 2.50 & $2.65 \pm 0.01$ & 106.02 & 0.56 \\
\hline \hline
\end{tabular}

${ }^{\mathrm{a}}$ mean $\pm \mathrm{SD}$

\section{Extraction recovery}

The mean extraction recovery values \pm RSD across four concentrations were $92.14 \% \pm 8.07 \%, 93.50 \% \pm 2.69 \%, 97.03 \% \pm 2.94 \%, 97.61 \% \pm 0.96 \%$ and $95.2 \% \pm 2.1 \%$ for internal standard that suggested good extraction recovery. Results are shown in Table III. 
Table III Extraction Recovery data

Tabela III Rezultati za Recovery nakon ekstrakcije

\begin{tabular}{|c|c|c|c|}
\hline $\begin{array}{l}\text { Added CHX } \\
\left(\mu \mathrm{g} \mathrm{mL} \mathrm{mL}^{-1}\right)\end{array}$ & $\begin{array}{l}\text { Determined CHX } \\
\left.(\mu \mathrm{g} \mathrm{mL})^{-1}\right)^{\mathrm{a}}\end{array}$ & $\begin{array}{c}\text { Recovery } \\
(\%)\end{array}$ & RSD (\%) \\
\hline 0.50 & $0.46 \pm 0.04$ & 92.14 & 8.07 \\
\hline 1.50 & $1.40 \pm 0.04$ & 93.50 & 2.69 \\
\hline 2.50 & $2.43 \pm 0.07$ & 97.03 & 2.94 \\
\hline 4.00 & $3.90 \pm 0.03$ & 97.61 & 0.96 \\
\hline
\end{tabular}

Stability

GCF samples may encounter different conditions that influence the stability of the samples during collection and analysis, thus stability experiments were performed. The results showed that GCF samples spiked with CHX are stable after three freeze-thaw cycles, after 16 hours in the autosampler and at room temperature for 2 hours. The study has shown that samples could be kept frozen at $-20^{\circ} \mathrm{C}$, for one month. The stability results are presented in Table IV.

Table IV Stability of CHX in GCF samples

Tabela IV Stabilnost CHX u GCF uzorcima

\begin{tabular}{ccc}
\hline \hline CHX $\left(\boldsymbol{\mu g} \mathbf{~ m L}^{-1}\right)$ in QC samples & \multicolumn{2}{c}{ Determined $\mathbf{C H \mathbf { X } ^ { \mathrm { a } }}$} \\
\hline Freeze-thaw stability & $\begin{array}{c}\text { Fresh samples } \\
\left(\mu \mathrm{gL}^{-1}\right)\end{array}$ & $\begin{array}{c}\text { Relative to fresh } \\
\text { sample }(\%)\end{array}$ \\
0.50 & $0.49 \pm 0.03$ & $101.01 \pm 1.78$ \\
4.00 & $4.08 \pm 0.17$ & $101.79 \pm 1.09$ \\
Short-term stability & & \\
0.50 & $0.48 \pm 0.13$ & $97.65 \pm 3.64$ \\
4.00 & $3.99 \pm 0.02$ & $98.81 \pm 1.72$ \\
& & \\
Autosampler stability & $0.47 \pm 0.24$ & $98.21 \pm 3.18$ \\
4.00 & $3.98 \pm 0.01$ & $99.67 \pm 0.78$ \\
Long-term stability & & \\
0.50 & $0.48 \pm 0.56$ & $98.63 \pm 1.30$ \\
4.00 & $3.97 \pm 0.69$ & $98.56 \pm 0.60$ \\
\hline \hline
\end{tabular}




\section{Method application}

In order to examine the potential of the method for clinical application, it was applied to analyse samples of GCF collected from patients suffering from chronic periodontitis after local application of the PerioChip ${ }^{\mathrm{TM}}$. The chromatogram of patient's GCF sample obtained 1 hour after the insertion of the PerioChip ${ }^{\mathrm{TM}}$ is presented in Figure 3.

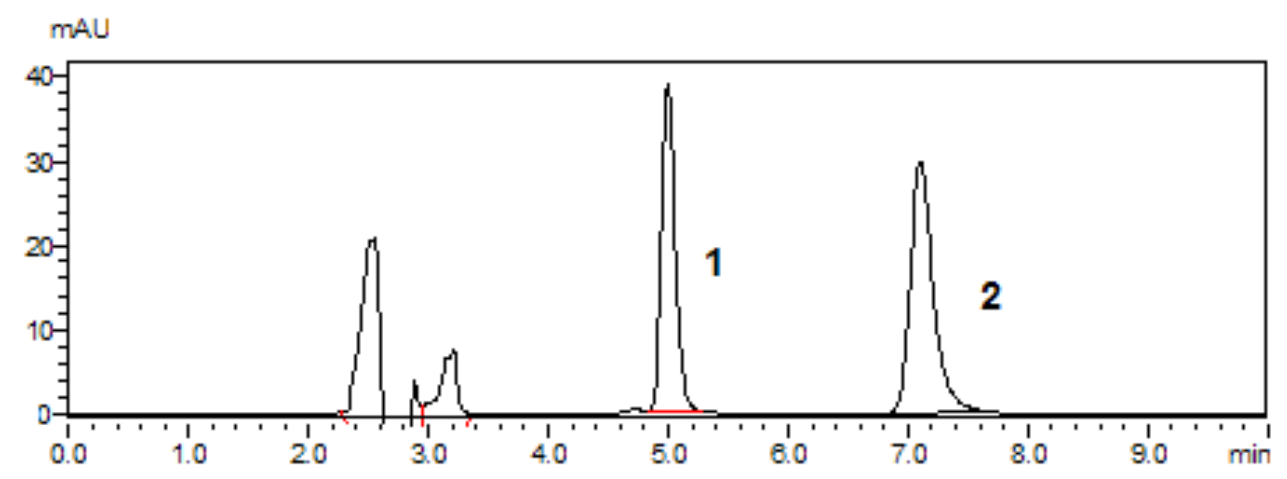

Figure 3. Representative chromatogram of a patient GCF sample obtained 1 hour after the application of the PerioChip (1-IS, 2-CHX)

Slika 3. Reprezentativni hromatogram uzorka GCF pacijenta dobijen 1 sat nakon primene PerioChip (1-IS, 2-CHX)

After the subgingival placement of the PerioChip ${ }^{\mathrm{TM}}$, we have found that the CHX in GCF reached maximum concentration of $1452.8 \mu \mathrm{g} \mathrm{mL} \mathrm{m}^{-1}$ after 1 hour. The concentration then decreased in the range from $1200.3 \mu \mathrm{g} \mathrm{mL}^{-1}-750.5 \mu \mathrm{g} \mathrm{mL}^{-1}$ in the next 70 hours and reached $500.5 \mu \mathrm{g} \mathrm{mL}^{-1}$ at the end of the study period. Mean CHX concentrations in GCF obtained from patients after PerioChip ${ }^{\mathrm{TM}}$ applications are shown in Table V. 
Table V Mean chlorhexidine concentrations in GCF obtained from 30 patients after PerioChip $^{\text {TM }}$ application

Tabela V Srednja vrednost koncentracije hlorheksidina u GFC dobijena analizom uzorka dobijenih od 30 pacijenata nakon primene PerioChip ${ }^{\mathrm{TM}}$

\begin{tabular}{ccc}
\hline \hline Time (h) & \multicolumn{2}{c}{ CHX $\left(\boldsymbol{\mu g} \mathbf{~ m L}^{-1}\right)$} \\
\hline \hline & Mean \pm SD & RSD (\%) ${ }^{\mathrm{a}}$ \\
24 & $1452.8 \pm 187.88$ & 12.93 \\
48 & $1200.3 \pm 255.98$ & 21.33 \\
96 & $911.9 \pm 81.22$ & 10.44 \\
144 & $783.6 \pm 74.32$ & 9.48 \\
168 & $750.5 \pm 62.39$ & 8.31 \\
\hline \hline
\end{tabular}

${ }^{a} \mathrm{RSD}$ - inter-individual variability of CHX concentration in GCF

It is noteworthy that CHX levels in GCF were maintained over $1000 \mu \mathrm{g} \mathrm{mL}^{-1}$ for about 72 hours and they remain above $125 \mu \mathrm{g} \mathrm{mL} \mathrm{m}^{-1}$ for up to seven days. This concentration has been reported to be the minimum inhibitory concentration (MIC) for more than $99 \%$ of bacterial flora isolated from periodontal pockets [7].

The results given in Table $\mathrm{V}$ suggest high inter-individual variability among the patients included in the study. This might be due to the variations in GCF flow, the great variability in GCF flow between patients with different degrees of periodontal inflammation as well as the reduction in the GCF flow rate that might be expected at the end of the treatment [7].

\section{Conclusion}

A simple isocratic RP HPLC method with UV detection for quantification of CHX in GCF has been developed and validated. The proposed method has been successfully applied to the analysis of GCF samples from patients suffering from chronic periodontal disease. Considering high sensitivity and small aliquots of biological sample required for sample analysis, this method can be easily applied for the therapeutic drug monitoring in patients undergoing therapy or pharmacokinetic evaluation of other drug delivery systems containing $\mathrm{CHX}$ used in periodontal treatment. 


\section{References:}

1. Soskolne WA. Subgingival delivery of therapeutic agents in the treatment of periodontal disease. Crit Rev Oral Biol M. 1997; 8(2):164-74.

2. Lamster IB, Ahlo JK. Analysis of gingival crevicular fluid as applied to the diagnosis of oral and systemic diseases. Ann N Y Acad Sci. 2007;1098: 216-29.

3. Patel PV. Gingival crevicular fluid (GCF): An oral biomarker in the diagnosis and quantification of periodontal diseases. J Invest Periodontol. 2010; 3 (6):45-63.

4. Slots J. Selection of antimicrobial agents in periodontal therapy. J Periodont Res. 2002; 37:389-98.

5. Perinetti G, Paolantonio M, Cordella C, D'Ercole S, Serra E, Piccolomini R. Clinical and microbiological effects of subgingival administration of two active gels on persistent pockets of chronic periodontitis patients. J Clin Periodontol. 2004; 31:273-81.

6. Greenstein G. Local drug delivery in the treatment of periodontal diseases: Asssesing the clinical significance of the results. J Periodontol. 2006; 77:656-78.

7. Schwach_Abdellaou K, Vivien-Castioni N, Gurny. Local delivery of antimicrobial agents for the treatment of periodontal diseases. Eur J Pharm Biopharm. 2000; 50:83-99.

8. Paolantonio M, D’Ercole S, Pilloni A, D’Archivio D, Lisanti L, Graziani F, Femminella B, Sammartino G, Perrilo L, Tete S, Perfetti G, Spoto G, Piccolomini R, Perinetti G. Clinical, microbiologic, and biochemical effects of subgingival administration of a xantan-based chlorhexidine gel in the treatment of periodontitis: a randomized multicenter study. J Periodontol. 2009; 80:1479-92.

9. Soskolne WA, Chajek T, Flashner M, Landau I, Stabholz A, KolatchB, Lerner EI. An in vivo study of the chlorhexidine release profile of the PerioChip ${ }^{\mathrm{TM}}$ in the gingival crevicular fluid, plasma and urine. J Clin Periodontol. 1998; 25:1017-21.

10. American Academy of Periodontology. The role of Controlled drug delivery for periodontitis. J Periodontol. 2000; 71:125-40.

11. Musteata FM, Pawliszyn J. Assay of stability, free and total concentration of chlorhexidine in saliva by solid phase extraction. J Pharm Biomed Anal. 2005;37: 1015-24.

12. Xue Y, Tang M, Hieda Y, Fujihara J, Takayama K, Takatsuka H, Takeshitta H. High-performance liquid chromatographic determination of chlorhexidine in whole blood by solid-phase extraction and kinetics following an intravenous infusion in rats. J Anal Toxicol. 2009; 33:85-91.

13. Kudo K, Ikeda n, Kiyoshima A, Hino $\mathrm{Y}$, Nishida $\mathrm{N}$, Inoue $\mathrm{N}$. Toxicological analysis of chlorhexidine in human serum using HPLC on a polymer-coated ODS column. J Anal Toxicol. 2002; 26:119-22.

14. Koss M, Castro C, Salum K, Lopez M. Enzymatic profile of gingival crevicular fluid in assotion with periodontal status. Lab med. 2009; 40:277-80.

15. Vineau DS, Kindberg CG, Development and validation of a sensitive method for tetracycline in gingival crevicular fluid by HPLC using fluorescent detection. J Pharm Biomed Anal. 1997; 16:111-17.

16. EMA, Guideline on bioanalytical method validation, EMEA/CHMP/EWP/192217/2009 Rev.1 Corr.* Committee for Medicinal Products for Human Use (CHMP). 


\title{
Razvoj i validacija RP-HPLC metode za određivanje hlorheksidina u gingivalnoj tečnosti
}

\section{Liljana Bogdanovska ${ }^{1 *}$, Sehmedin Saliu ${ }^{2}$, Mirjana Popovska ${ }^{2}$, Aneta Dimitrovska ${ }^{1}$, Liljana Ugrinova ${ }^{1}$, Rumenka Petkovska $^{1}$}

${ }^{1}$ Katedra za primenjenu hemiju i farmaceutsku analizu, Univerzitet „Ćirilo i Metodije” - Farmaceutski fakultet, Majke Tereze 47, Skoplje, Republika Makedonija

${ }^{2}$ Katedra za oralnu patologiju i periodontologiju, Univerzitet „Ćirilo i Metodije” Stomatološki fakultet, Majke Tereze 47, Skoplje, Republika Makedonija

"autor za prepisku, e-mail: $\underline{\text { lbogdanovska@,ff.ukim.edu.mk }}$

\begin{abstract}
Kratak sadržaj
Optimizirana je i validirana revezno-fazna HPLC metoda sa UV detekcijom za određivanje hlorheksidina u tečnosti gingivalnog sulkusa (eng. Gingival Crevicular Fluid GCF) primenom hlorfeniramina kao internog standarda. Hromatografska analiza urađena je na Discovery C18 HPLC koloni sa mobilnom fazom koja se sastojala od $0,01 \mathrm{~mol} \mathrm{~L}^{-1}$ fosfatnog pufera $(\mathrm{pH}=3,0)$, trietilamina $\mathrm{i}$ acetonitrila u odnosu $(66: 1: 33, V / V / V)$. Pod optimalnim hromatografskim uslovima ispitana je linearnost $\mathrm{u}$ opsegu koncentracija od $0,5 \mu \mathrm{g} \mathrm{mL} \mathrm{m}^{-1}$ do 5,0 $\mu \mathrm{g} \mathrm{mL}^{-1}$ sa sledećim vrednostima za limite: LOD $0,07 \mu \mathrm{g} \mathrm{mL}^{-1}$ I LLOQ $0,5 \mu \mathrm{g} \mathrm{mL}^{-1}$. Metoda je uspešno primenjena za određivanje koncentracije hlorheksidina u GCF kod pacijenata sa hroničnom parodontopatijom nakon primene PerioChip ${ }^{\mathrm{TM}}$.
\end{abstract}

Ključne reči: hlorheksidin diglukonat, PerioChip ${ }^{\mathrm{TM}}$, RP-HPLC, tečnost gingivalnog sulkusa, parodontopatija 